\title{
PENGARUH KOMPETENSI PUSTAKAWAN PELATIHAN TERHADAP KINERJA
}

\author{
Moch. Fikriansyah Wicaksono \\ Staf Pengajar Ilmu Perpustakaan dan Informasi Islam, Fakultas Ushuluddin, \\ Adab, dan Dakwah, Institut Agama Islam Negeri Tulungagung \\ Novi Nur Ariyanti \\ Mahasiswa Ilmu Perpustakaan dan Informasi Islam, Fakultas Ushuluddin, \\ Adab, dan Dakwah, Institut Agama Islam Negeri Tulungagung \\ fikriansyahw24@gmail.com
}

\begin{abstract}
Introduction. The school library is one of the school components to support the information needs of teachers and students. Therefore, in realizing a good library, a competent librarian is needed. In Law no. 43 of 2007, it is stated that in managing and serving the library users, it can be done by a librarian whose competence obtained from college education or training. In recent years there are many school librarians whose competence is obtained from training, whether government or nongovernment institutions organize it. It is interesting to examine further how good the competence of these school librarians influences their performance in managing school libraries. Data Collection Method. This research uses the explanative quantitative approach with survey method on school librarians with training background. Analusis Data. Then, to see whether there is any effect on the librarians' performance, the general, core, and special variables are analyzed by using Smart PLS. Result and Discussions. The results of this study indicate that there is no influence on the librarians' performance in
\end{abstract}


core competence and specific competence variables, while the general competence variable shows a significant influence on the librarians' performance. Conclusions. From these results, it can be concluded that librarians with training backgrounds have less than maximum performance in serving and managing the school libraries.

Keywords: School librarian; Training librarian; Librarian competence;

\begin{abstract}
Abstrak
Pendahuluan. Perpustakaan sekolah merupakan salah satu lembaga penunjang kebutuhan informasi bagi guru dan siswa sekolah. Maka dari itu, untuk mewujudkan perpustakaan yang baik diperlukan pustakawan yang berkompeten. Di dalam UU No. 43 tahun 2007 dijelaskan bahwa untuk mengelola dan melayani pemustaka dapat dilakukan oleh pustakawan yang kompetensinya diperoleh dari pendidikan atau pelatihan. Fenomena yang muncul dalam beberapa tahun ini adalah banyaknya pustakawan sekolah yang kompetensinya diperoleh dari pelatihan, baik pelatihan yang diselenggarakan oleh lembaga pemerintah atau lembaga non pemerintah. Hal ini menjadi menarik untuk dikaji lebih jauh tentang seberapa jauh kompetensi para pustakawan pelatihan ini berpengaruh pada kinerja mereka dalam mengelola perpustakaan sekolah. Metode penelitian. Penelitian ini menggunakan pendekatan kuantitatif eksplanatif dengan metode survey pada pustakawan sekolah yang berlatar belakang pelatihan. Data analisis. Kemudian untuk melihat ada tidaknya pengaruh kompetensi terhadap kinerja dilakukan analisa pengaruh dari variabel kompetensi umum, inti dan khusus dengan menggunakan Smart PLS. Hasil dan Pembahasan. Hasil penelitian ini menunjukkan bahwa pada variabel kompetensi inti dan kompetensi khusus tidak terdapat pengaruh pada kinerja pustakawan, sedangkan pada variabel kompetensi umum menunjukkan pengaruh yang signifikan pada kinerja pustakawan pelatihan. Kesimpulan. Dari hasil tersebut dapat disimpulkan bahwa pustakawan
\end{abstract}


yang memiliki latar belakang pelatihan memiliki kinerja yang kurang maksimal dalam melayani dan mengelola perpustakaan sekolah.

Kata Kunci: Pustakawan sekolah; Pustakawan pelatihan; Pustakawan diklat; Kompetensi pustakawan

\section{A. Pendahuluan}

Perpustakaan yang baik dapat dinilai dari berbagai sudut pandang. Salah satunya ialah dari sudut layanan yang diberikan pustakawan kepada pemustaka. Layanan yang baik secara tidak langsung memberikan dampak positif pada minat seseorang dalam membaca (Makin, 2010), rasa puas seseorang dan sikap loyal pengguna perpustakaan (Tamara, 2014; Habir, 2015). Tentunya layanan yang diberikan tidak terlepas dari kemampuan pustakawan dalam mengelola perpustakaan. Seseorang yang dianggap mampu adalah mereka yang memiliki kompetensi dibidangnya. Sehingga dalam kaitannya memajukan perpustakaan maka dibutuhkan pustakawan yang kompeten dalam mengelola dan memberikan layanan pada pemustaka. Sebagaimana pernyataan Sulistyo Basuki (1993:8) putakawan ialah orang yang memberikan dan melaksanakan kegiatan perpustakaan dalam usaha pemberian layanan kepada masyarakat sesuai dengan misi yang diemban oleh badan induknya berdasarkan ilmu perpustakaan, dokumentasi, dan informasi yang diperolehnya melalui pendidikan.

Untuk mencapai perpustakaan yang baik tentu di butuhkan Sumber Daya Manusia yang berkualitas. Sumber Daya Manusia yang berkualitas tersebut tidak lain adalah pustakawana. Dengan kinerja dan hasil kerja yang baik oleh pustakawan tentu tidak mungkin perpustakaan mengalami kemunduran, dan justru memberikan dampak postif bagi pemustaka. Pustakawan yang baik tentu memiliki kompetensi yang baik. Dapat dilihat dari dua penilaian, internal pustakawan dan eksternal pustakawan. Internal pustakawan tidak lain ialah rasa tanggung jawab terhadap kinerja yang tumbuh dari dalam diri pustakawan. Eksternal pustakawan 
ialah kinerja yang di pengaruhi dari luar diri pustakawan di antarannya, pendidikan yang ahli dalam bidangnya, mampu berfikir praktis, mampu dalam penguasaan teknis perpustakan. Selain itu, tingkat keberhasilan dalam menyelesaikan pekerjaan sesuai dengan target yang sudah di tentukan oleh perpustakaan. Tentunya kompetensi ini di lakukan sesuai dengan ketentuan instansi.

Di dalam UU Republik Indonesia no.43 tahun 2007 dijelaskan bahwa pustakawan adalah seorang yang memiliki kompetensi yang diperoleh melalui pendidikan dan pelatihan kepustakawanan serta mempunyai tugas dan tanggung jawab untuk melaksanakan pengelolaan dan pelayanan perpustakaan. Dari peraturan ini kita dapat mengambil kesimpulan bahwa terdapat dua jenis pustakawan yaitu pustakawan yang memperoleh kompetensinya dari hasil pelatihan pustakawan dan hasil dari pendidikan pustakawan. Kemudian fenomena yang muncul dalam beberapa tahun belakangan ini adalah banyaknya pustakawan sekolah yang latar belakang aslinya adalah seorang guru kelas, yang kemudian mereka mendapat tugas tambahan sebagai pustakawan di sekolah mereka. Fenomena ini tidak terlepas dari dua aturan yang dikeluarkan oleh permendikbud dan kementrian pendidikan nasional.

Pertama adalah Peraturan Menteri Pendidikan dan Kebudayaan No. 17 tahun 2016 tentang tambahan penghasilan bagi guru PNS daerah dan teknis penyaluran tunjangan profesi. Pada Peraturan Menteri Pendidikan dan Kebudayaan tersebut dijelaskan bahwa seorang guru diberikan beban kerja minimal 24 jam tatap muka dalam satu minggu. Peraturan tersebut menimbulkan efek tidak baik bagi guru-guru, karena sesuai hasil dilapangan masih banyak ditemukan guru di berbagai instansi mulai tingkat Sekolah Dasar, Sekolah Menengah Pertama, dan Sekolah Menengah Atas tidak sedikit ditemukan guru kekurangan jam mengajar dari batas minimum yang sudah ditetapkan. Sehingga dampak yang diterima oleh guru adalah guru tidak akan mendapatkan tunjangan profesi dan tambahan penghasilan. Untuk mengatasi masalah tersebut 
guru dapat menambah kekurangan jam mengajarnya dengan tugas tambahan sebagai pustakawan atau kepala perpustakaan dengan rincian jam mengajar dihitung sebesar 12 jam. Dengan jam mengajar 12 jam sebagai pustakawan guru tidak lagi tidak mendapat tunjangan profesi. Guru kelas dapat memenuhi beban jam mengajar yang telah di tentukan oleh peraturan pemerintah pusat. Tidak melihat sanggup atau tidak sanggup untuk di tempatkan sebagai pustakawan.

Kedua adalah peraturan kementrian pendidikan nasional nomor 25 tahun 2008. Di dalam peraturan ini dijelaskan bahwa kualifikasi menjadi kepala perpustakaan atau pustakawan dapat ditempuh melalui 2 cara. Pertama, melalui jalur pendidik, dimana seorang calon kepala perpustakaan atau pustakawan minimal berkualifikasi D4 atau S1 dan memiliki sertifikat kompetensi pengelolaan perpustakaan sekolah. Kedua, adalah kepala perpustakaan atau pustakawan dari jalur tenaga kependidikan, yang kualifikasinya minimal D2 ilmu informasi dan perpustakaan dan D2 non ilmu informasi dan perpustakaan dengan disertai sertifikat kompetensi pengelolaan perpustakaan sekolah. Peraturanperaturan di atas seolah-olah memberikan legalitas semua orang untuk bisa menjadi pustakawan atau kepala perpustakaan, walaupun syarat itu diperoleh dengan jalur pelatihan pustakawan.

Selanjutnya menarik untuk diteliti lebih jauh tentang kemampuan pustakawan hasil pelatihan ini dalam mengelola perpustakaan sekolah mereka. Terdapat beberapa penelitian terdahulu tentang uji pengaruh kompetensi pustakawan terhadap kinerja pustakawan, seperti yang dilakukan oleh Nurcahayanti (2017). Tujuan yang dicapai dari penelitian tersebut adalah menguji dan menganalisis seberapa besar pengaruh kompetensi pustakawan terhadap kinerja pustakawan pada sebagian perpustakaan khusus diantaranya, perpustakaan ATKP, AAL, PoltekPel, PoltekPol, dan PusdikKP. Hasil dari penelitian tersebut menyatakan kompetensi pustakawan berpengaruh besar terhadap kinerja dan hasil kerja pustakawan, Hasil penelitian ini 
menyatakan hasil yang tidak jauh berbeda dengan penelitian yang telah dilakukan oleh Kartikasari (2013). Kartika (2013) mencoba melihat ada tidaknya pengaruh kompetensi pustakawan dengan kinerja pustakawan. Hasil penelitian Kartika menyatakan bahwa terdapat pengaruh yang signifikan antara kompetensi pustakawan dengan kinerja dan hasil kerja pustakawan. Sejalan juga dengan penelitian keduanya, penelitian yang dilakukan Ardi (2015) yang mencoba melihat korelasi kompetensi pustakawan pada kinerja pustakawan di perpustakaan UIN Sunan Kalijaga Yogyakarta. Penelitian yang dilakukan oleh Ardi menunjukkan bahwa terdapat korelasi besar dan signifikan antara kompetensi pustakawan pada kinerja pustakawan.

Dari beberapa kajian dan penelitian tentang kompetensi pustakawan dan kinerja pustakawan di atas menunjukkan bahwa kompetensi memiliki hubungan dan pengaruh signifikan terhadap kinerja. Tetapi sejauh kajian dan penelitian terdahulu belum ditunjukkan parameter ukur bahwa kompetensi pustakawan yang diperoleh dari pelatihan memberikan pengaruh pada kinerja dan hasil kerja pustakawan. Hal inilah yang menjadi perbedaan dengan penelitian terdahulu. Penelitian terdahulu hanya melihat pengaruh kompetensi terhadap kinerja pada sampel pustakawan yang diperoleh dari pendidikan pustakawan. Sedangkan pada penelitian ini lebih menunjukkan pada sejauh mana pengaruh kompetensi dari hasil pelatihan berpengaruh pada kinerja dan hasil kerja pustakawan.

Beberapa peneliti telah menyelesaikan penelitian tentang pengaruh kompetensi pustakawan terhadap kinerja pustakawan. Salah satunya ialah penelitian yang dilakukan Kartikasari (2013); Aryadi (2015); dan Nurcahayati (2016) yang melihat pengaruh kompetensi pustakawan terhadap kinerja pustakawan. Hasil penelitian dari ketiga peneliti tersebut menyatakan bahwa kompetensi pustakawan berpengaruh besar terhadap kinerja pustakawan. Tetapi hasil penelitian tersebut tidak dapat digunakan sebagai acuan untuk menjelaskan kompetensi pustakawan di 
berbagai jenis pustakawan. Padahal jenis pustakawan sangat erat kaitannya dengan tempat mereka bekerja. Apabila mereka bekerja di perpustakaan perguruan tinggi maka mereka dapat dikatakan sebagai pustakawan perguruan tinggi yang tentu memiliki kemampuan dan kompetensi yang berbeda dengan pustakawan yang bekerja di perpustakaan sekolah atau perpustakaan daerah. Ketiga peneliti di atas hanya menjelaskan pengaruh kompetensi putakawan perguruan tinggi pada kinerja pustakawan.

Pokok persoalan yang membedakan penelitian pertama dengan penelitian ini adalah penelitian pertama yang menitik beratkan kajian pada lingkup perpustakaan perguruan tinggi dan perpustakaan khusus seperti Universitas Negeri Semarang , UIN Sunan Kalijaga Yogyakarta dan perpustakaan AL, PoltekKP, ATKP, PoltekPel dan PusdikPol. Sedangkan pada penelitian ini memfokuskan pada ruang lingkup perpustakaan yang berada di sekolah. Baik sekolah tingkat Sekolah Dasar, Sekolah Menengah Pertama dan Sekolah Menengah Atas. Perbedaan kedua terletak pada focus pustakawan. Ketiga peneliti di atas memfokuskan pada pustakawan yang berlatar belakang pendidikan D3 dan S1 bidang perpustakaan. Sedangkan pada penelitian ini menitik beratkan pada pustakawan yang berlatar belakang kepustakawannya diperoleh dari hasil pelatihan. Baik pelatihan yang diselenggarakan oleh lembaga diklat negeri atau swasta.

Selanjutnya untuk menjelaskan pengaruh kompetensi terhadap kinerja pustakawan, pada kajian penelitian ini menggunakan Standar Kompetensi Kerja Nasional Indonesia yang dikeluarkan oleh Perpustakaan Nasional. Sedangkan teori dan konsep kinerja pustakawan diambil dari kinerja yang diungkapkan oleh Darmono (2016). Dalam standart kompetensi tersebut memuat kompetensi umum, kompetensi inti, dan kompetensi khusus.

1. Kompetensi Umum

Kompetensi umum merupakan kompetensi tingkat pertama yang wajib dimiliki oleh setiap pustakawan, dengan tujuan guna memermudah dalam menjalankan 3 tugas-tugas 
pustakawan, meliputi: (1) Menjalankan Komputer Tingkat Pertama atau tingkat dasar, (2) Menyusun Rancangan Kerja yang Akan Dilaksanakan Oleh Perpustakaan, (3) Membuat dan Menyusun Laporan Kerja dan Hasil Kerja Perpustakaan Sebagai Laporan Hasil Kerja Suatu Program yang Telah di Rencanakan Sebelumnya. Kompetensi Umum Ini Erat Hubungannya Dengan Kompetensi Inti dan Khusus yang Harus Dimiliki dan Sebagai Bentuk Tanggung Jawab Khusus Oleh Pustakawan.

2. Kompetensi Inti

Kompetensi inti merupakan kompetensi fungsional yang pasti dan wajib dikuasai oleh setiap pustakawan sebagai penunjang dalam mengerjakan tugas-tugas perpustakaan. Kompetensi inti meliputi unit-unit kompetensi yang diperlukan untuk menyelesaikan tugas-tugas inti, sehingga pustakawan harus menguasainya. Kompetensi inti meliputi: (1) Melakukan Seleksi koleksi pada Perpustakaan, (2) Melakukan Pengadaan dan Sirkulasi Bahan Pustaka, (3) Melakukan Pendataan dan Pengatalogan Subyek, (4) Melakukan Pendataan dan Pengatalogan Deskriptif, (5) Melakukan Perawatan dan Penataan Bahan Pustaka, (6) Melakukan Layanan Sirkulasi Bahan Pustaka, (7) Melakukan Layanan Referensi Bahan Pustaka, (8) Melakukan Kegiatan Literasi Informasi, (9) Melakukan Promosi pada Perpustakaan, (10) Melakukan Penelusuran Informasi Sederhana.

3. Kompetensi Khusus

Kompetensi khusus adalah kompetensi lanjutan yang bersifat spesifik, meliputi: (1) Merancang Tata Ruang dan Perangkat Perpustakaan, (2) Melakukan Perawatan dan Perbaikan Bahan Pustaka, (3) Membuat Penelusuran Informasi Kompleks, (4) Melakukan Literatur Sekunder, (5) Melakukan Kajian Pustaka, (6) Membuat Karya Tulis Ilmiah. 
Kemudian penilaian kinerja pustakawan dijelaskan kembali oleh Darmono (2016) dalam pelatihan kepala perpustakaan sekolah. Dalam pelatihan tersebut Darmono menjelaskan mengenai tiga komponen penilaian kinerja pustakawan sekolah/madrasah yang dinilai berpengaruh.

Pertama penilaian input, yaitu kemampuan atau kompetensi yang dimiliki sebagai penunjang pekerjaannya. Orientasi ini memfokuskan objek penelitiannya pada karakteristik individu, dalam hal ini objek penilaian berupa komitmen tenaga perpustakaan sekolah terhadap pelaksanaan tugas dengan membuat rencana program kerja yang akan dilaksanakan di perpustakaan. Penilaian ini sebagai bentuk penilaian pertama dalam penilaian pustakawan.

Kedua penilaian proses, yaitu penilaian terhadap prosedur pelaksanaan pekerjaan pustakawan. Penilaian pada orientasi ini dikhususkan pada perilaku pustakawan perpustakaan sekolah dalam melaksanakan tugas pokok, fungsi dan tanggung jawabnya, yakni melaksanakan fungsi kegiatan operasional pada perpustakaan sekolah. Tugas dan kegiatan ini meliputi pelaksanaan program, pengembangan koleksi, organisasi layanan, penerapan teknologi, promosi dan literasi.

Ketiga penilaian output, yaitu Penaksiran hasil kerja yang telah dilaksanakan dari tugas pokok, fungsi dan tanggungjawabnya. Penilaian ini dapat dilihat dari integritas, etos kerja, dan pengembangan profesinalitas pustakawan, dan evaluasi program kerja.

Nurcahayati (2016) sebagaimana yang di kutip dari Supriyanto dan Machfudz (2010:141) menyatakan standar kinerja seseorang di nyatakan baik apanbil menyangkut beberapa factor seperti, kualitas,kuantitas, kedisiplinan, ketepatan waktu, kreatifitas dan inovasi, kehadiran, kerjasama tim, bertanggungjawab dan melakukan perencanaan kerja. Kompetensi yang semestinya dimiliki oleh setiap pustakawan sebagai bentuk kompetensi keahlian khusus yaitu hard skill dan soft skill Nurcahayati (20016) yang dikutip dari Suherman (2009:101). 
Untuk dapat mencapai target yang telah di tentukan sebagai tolak ukur secara umum, perlunya sebuah kompetensi khusus yang wajib dimiliki oleh setiap pustakawan, baik pustakawan pelatihan maupun pustakawan pendidikan. Komptensi tersebut berguna sebagai tolak ukur kerja yang telah di embannya sebagai pustakawan.

Dengan demikian sudah semestinya pustakawan memiliki keahlian khusus untuk membentuk pola bekerja yang efektif, sehingga akan menghasilkan hasil kerja sesuai dengan kompetensi yang di harapkan oleh standard tempat bekerja. Sejauh ini tidak jarang pustakawan berkecenderungan merasa puas atas hasil kerja yang telah di lakukan, tanpa menilik kembali standar kerja dari waku kewaktu terus meningkat. Hal tersebut sudah semestinya pustakawan dituntut untuk lebih. Tentunya hasil kerja pustakawan berdampak langsung terhadap minat baca pemustaka.

\section{Metode Penelitian}

Penelitian ini merupakan penelitian kuantitatif eksplanatif dimana bertujuan untuk melihat pengaruh kompetensi pustakawan pelatihan terhadap kinerja pustakawan. Metode dalam pengumpulan data adalah metode survey dengan teknik penarikan sampel menggunakan Simple Random Sampling. Selanjutnya hasil data yang diperoleh diolah menggunakan Smart PLS 3.0. Ada tidaknya pengaruh antara variabel kompetensi pada kinerja dengan menggunakan program smartPLS, yang dilihat dari T Statistic dan nilai P Values. Jika nilai T Statistic $>$ T tabel $(2,024)$ dan P Values < 0,05 maka dapat dikatakan ada pengaruh yang signifikan (Abdillah W. \& Hartono J., 2015). Selanjutnya dari data yang diperoleh dilakukan analisis dengan menggunakan teori, dan kajian literatur tentang kompetensi dan kinerja pustakawan.

\section{Hasil Dan Pembahasan}

\section{a. Hasil Olah Data}

Hasil uji pengaruh menggunakan program smartPLS 3.0 dengan melihat T Statistic dan nilai P Values. Jika nilai T Statistic 
$>$ T tabel $(2,024)$ dan $\mathrm{P}$ Values $<0,05$ maka dapat dikatakan ada pengaruh yang signifikan (Abdillah W. \& Hartono J., 2015). Berikut ini tabel pengaruh variabel kompetensi pustakawan pelatihan terhadap kinerja pustakawan:

Tabel 1. Pengaruh Kompetensi pada Kinerja Pustakawan Pelatihan

\begin{tabular}{ccc}
\hline & T- Statistics & P Values \\
\hline K. Umum -> Kinerja & 4,105 & 0,000 \\
\hline K. Inti -> Kinerja & 1,538 & 0,125 \\
\hline K. Khusus -> Kinerja & 0,822 & 0,411 \\
\hline
\end{tabular}

Dari tabel 1 di atas dapat diketahui hasil pengaruh kompetensi pustakawan pelatihan terhadap kinerja pustakawan. Pada variabel kompetensi umum menunjukkan $P$ Values 0,000 $<0,050$ dan T Statistic 4,105 > 2,024. Maka dapat disimpulkan bahwa terdapat pengaruh pada kompetensi umum pada kinerja pustakawan pelatihan. Kemudian pada variabel kompetensi inti menunjukkan $P$ Values 0,125>0,050 dan T Statistic 1,538 <2,024. Maka tidak terdapat pengaruh antara kompetensi inti terhadap kinerja pustakawan. Variabel ketiga yakni kompetensi khusus menunjukkan $P$ Values $0,411>0,050$ dan T Statistic 0,822<2,024. Maka dapat disimpulkan tidak terdapat pengaruh antara variabel kompetensi khusus terhadap kinerja pustakawan pelatihan.

\section{B. Pembahasan}

Dari hasil uji statistik di atas dapat diketahui bahwa kompetensi umum saja yang berpengaruh pada kinerja pustakawan dalam mengelola perpustakaan sekolah, sedangkan pada kompetensi inti dan kompetensi khusus tidak menunjukkan pengaruhnya pada kinerja. Tentu hasil ini sedikit banyak akan berpengaruh pada layanan yang diberikan perpustakaan bagi penggunanya. Karena salah satu indikator layanan perpustakaan yang baik adalah ditunjukkan dari kemampuan pustakawan dalam mengelola perpustakaan. 
Jika dilihat dari indikator kompetensinya, hal yang berpengaruh pada kompetensi umum ini terlihat pada kemampuan dalam pengoperasian komputer, penyusunan rencana kerja dan pembuatan laporan kerja pada perpustakaan. Padahal untuk memberikan layanan yang maksimal pustakawan perlu memahami dan menguasai kegiatan inti dari perpustakaan, seperti membuat catalog, menyusun nomor klasifikasi, membuat panduan literasi, mengoperasikan OPAC/ SLIMS, dan meningkatkan kemampuannya dengan membuat kajian tentang perpustakaan. Kegiatan-kegiatan tersebut terdapat pada indikator dari variabel kompetensi inti dan kompetensi khsusus.

Sedangkan hasil penelitian ini menunjukkan pada kompetensi inti dan kompetensi khusus tidak berpengaruh pada kinerja pustakawan dalam mengelola perpustakaan. Kompetensi inti SKKNI ini meliputi: melakukan pengadaan bahan perpustakaan, Melakukan seleksi bahan perpustakaan, melakukan pengatalogan subyek, melakukan pengatalogan deskriptif, melakukan layanan sirkulasi, melakukan perawatan bahan perpustakaan, melakukan penelusuran informasi sederhana,, melakukan layanan referensi, melakukan kegiatan literasi informasi, melakukan promosi perpustakaan. Sedangkan pada kompetensi khusus meliputi perencanaan perabot dan tata ruang perpustakaan, melakukan perbaikan dan perawatan bahan perpustakaan, membuat literatur sekunder, melakukan kajian perpustakaan, melakukan penelusuran informasi kompleks, membuat karya tulis ilmiah.

Maka dapat disimpulkan bahwa faktor penyebab kurang maksimalnya kinerja pustakawan pelatihan dalam mengelola perpustakaan sekolah adalah ketidakmampuan pustakawan ini dalam menguasai aspek kompetensi ini dan khusus. Padahal dalam mengelola perpustakaan dituntut untuk professional dalam melakukan tugasnya. Sifat professional ini dapat tercapai salah satunya dengan menguasai kemampuan yang sudah sesuai standart yang ditetapkan. Seorang yang bekerja dibidang apapun dikatakan professional tidak cukup hanya bermodal ijazah akademik, 
melainkan juga wajib memenuhi standart kompetensi yang dapat dipertanggungjawabkan dan dapat diuji tingkat kompetensinya (Kartikasari, 2013). Hasil penelitian ini tidak sejalan dengan data yang ditemukan Fatmawati (2015). Di dalam artikelnya tentang "Mengoptimalkan peran pustakawan sekolah dan guru pustakawan dalam proses pembelajaran" Fatmawati menjelaskan bahwa di dalam Permendiknas nomor 25 tahun 2008 bahwa tenaga perpustakaan sekolah harus memenuhi pendidikan minimal S1 dan memiliki sertifikat kompetensi pengelolaan perpustakaan. Fatmawati (2015) menyebutkan tidak menemukan sertifikat yang dimiliki pustakawan sekolah ini, sehingga berdampak pada keahlian dalam mengelola perpustakaan.

Pustakawan pelatihan sejatinya adalah guru kelas yang diberikan tugas tambahan untuk mengelola perpustakaan sekolah. Maka dari itu untuk meningkatkan pelayanan perpustakaan harus memuat terobosan baru di lingkungan sekolah. Terobosan itu dapat diwujudkan dalam beberapa cara, pertama adanya kolaborasi antara tiga elemen sekolah yakni pustakawan sekolah, guru dan kepala sekolah. Kolaborasi dapat berupa evaluasi hasil belajar, berdiskusi secara bersama antara guru dan pustakawan dalam hal kebutuhan informasi yang diperlukan para pemustaka. saling berdiskusi untuk membuat sebuah kegiatan yang berbasis perpustakaan sekolah, dan menentukan prosedur penilaian dan tanggungjawab dari segala kegiatan.

Terobosan kedua berada pada pemangku kebijakan dalam hal ini adalah kepala perpustakaan. Kepala perpustakaan sebagai pemegang kebijakan tertinggi di perpustakaan harus dapat merumuskan konsep dan standart penilaian kinerja layanan. Standar ini dapat berupa konseptual ataupun operasinal. Dua terobosan itu setidaknya dapat menjadikan perpustakaan lebih baik dalam pelayanannya dan pustakawan hasil pelatihan dapat meningkatkan kompetensinya. Australian School Library Association (ASLA) menjelaskan setidaknya ada tiga peran utama dari guru yang bekerja menjadi pustakawan sekolah. Pertama sebagai pembuat 
kurikulum sekolah (as curriculum leader). Pembuatan kurikulum ini mungkin berbeda dengan sekolah-sekolah di Indonesia, karena kebanyakan sekolah di Indonesia yang membuat kurikulum adalah guru sekolah tanpa melibatkan pustakawan sekolah. Kedua berperan sebagai spesialis informasi (as information specialists). Peran ini mengharuskan seorang guru yang juga pustakawan sekolah dapat mengetahui berbagai informasi yang mungkin dibutuhkan siswa dan orang-orang di lingkungan sekolah. Ketiga pustakawan guru berperan sebagai manajer layanan informasi (as information services manager).

\section{Penutup}

Dari hasil dan pembahasan, maka dapat diambil kesimpulan dan saran sebagai berikut:

1. Variabel kompetensi yang secara jelas memperngaruhi kinerja pustakawan dalam mengelola perpustakaan sekolah adalah kompetensi umum.

2. Pada variabel kompetensi inti dan khusus yang dimiliki pustakawan pelatihan dihasilkan tidak terdapat pengaruh terhadap kinerja pustakawan dalam mengelola perpustakaan sekolah.

3. Salah satu faktor penyebab kurang maksimalnya kinerja pustakawan pelatihan dalam mengelola perpustakaan sekolah dikarenakan pustakawan pelatihan kurang menguasai kompetensi inti dan khusus. Sehingga berdampak pada buruknya layanan di perpustakaan sekolah.

4. Saran bagi peneliti selanjutnya bahwa kajian penelitian ini hanya menggunakan pupulasi kecil yakni kabupaten sidoarjo. Guna mendapatkan hasil kajian yang lebih komprehensif maka perlu dilakukan penelitian pada populasi yang lebih besar lagi.

Saran bagi pemegang kebijakan sekolah adalah dengan temuan hasil yang menyatakan bahwa kurang maksimalnya 
kompetensi yang dimiliki pustakawan sehingga berdampak negative terhadap hasil kerja pustakawan, maka dalam proses perekrutan pustakawan, kepala sekolah hendaknya memilih pustakawan yang memiliki latar belakang pendidikan perpustakaan, baik lulusan D3,S1 atau S2 perpustakaan. 


\section{DAFTAR PUSTAKA}

Abdillah, W., \& Hartono, J. (2015). Partial Least Square (pls). (D. Prabantini, Ed.) (1st ed.). Yoyakarta: Andi Offset.

Aryadi, A.Y. (2015). Pengaruh kompetensi terhadap kinerja pustakawan di perpustakaan UIN Sunan Kalijaga Yogyakarta (Tesis, Universitas Islam Negeri Sunan Kalijaga Yogyakarta).

Basuki, Sulistyo. 1993. Pengaruh Ilmu Perpustakaan. Jakarta: Gramedia Pustaka Utama.

Darmono. (April, 2016). Standar kualifikasi, kompetensi, dan penilaian kinerja kepala perpustakaan sekolah/madrasah. Disampaikan Pada Pelatihan Manajemen Perpustakaan Sekolah di Kabupaten Sumenep.

Fatmawati, E. (2015). Mengoptimalkan peran pustakawan sekolah dan guru pustakawan dalam proses pembelajaran. Prosiding: seminar lokakarya dan workshop kepustakaawanan nasional Indonesia

Habir. (2015). Pengaruh layanan perpustakaan terhadap minat kunjung pemustaka di perpustakaan Stikes Mega Rezky Makassar. Jurnal Ilmu Perpustakaan, Informasi, dan Kearsipan Khizanah Al-Hikmah, 3(2), 156-171.

Kartikasari, D. (2013). Pengaruh kompetensi pustakawan terhadap kinerja perpustakaan di UPT perpustakaan Universitas Negeri Semarang (Skripsi, Universitas Negeri Semarang). Tersedia dari http://eprints.undip.ac.id/40780/

Makin, A. H. (2010). Pengaruh pelayanan perpustakaan sekolah dalam menumbuhkan minat baca peserta didik MI Darul Ulum Bangilan Kecamatan Keras Kabupaten Bojonegoro (Tesis, Universitas Islam Negeri Surabaya). Tersedia dari http://digilib.uinsby.ac.id/8189/

Nurcahayanti, E. (2017). Pengaruh kompetensi pustakawan terhadap kinerja pustakawan dalam pelayanan pengguna 
di perpustakaan khusus" "(studi eksplanatif pengaruh kompetensi pustakawan terhadap kinerja pustakawan dalam pelayanan di perpustakaan AAL, ATKP, PoltekKP, PoltekPel, dan PusdikPol di Daerah Surabaya dan Sidoarjo)" (Skripsi, Universitas Airlangga Surabaya). Tersedia dari http:// repository.unair.ac.id/54979/

Republik Indonesia. Peraturan Menteri Pendidikan dan Kebudyaan Nomor 17 Tahun 2016 Tentang Petunjuk Teknis Penyaluran Tunjangan Profesi dan Tambahan Penghasilan Bagi Guru Pegawai Negeri Sipil Daerah

Republik Indonesia. Undang-Undang Republik Indoenesia Nomor 43 Tahun 2007 Tentang Perpustakaan

Perpustakaan Nasional RI. (2011). Standar Nasional Pepustakaan Bidang Perpustakaan Sekolah dan Perpustakaan Perguruan Tinggi. Jakarta: Perpustakaan Nasional RI.

Australia Library and informations Association. (2015). Standarts of Proffesional Excellence for Teacher.

Tamara, L. (2014). Pengaruh kualitas layanan terhadap kepuasan dan loyalitas pemustaka di Perpustakaan Nasional Republik Indonesia. (Tesis, Institut Pertanian Bogor). Tersedia dari http://repository.ipb.ac.id 
